\title{
Just War Theory Symposium: Introduction
}

\section{Adam Cebula ${ }^{1}$}

Received: 22 April 2020 / Accepted: 22 April 2020 /

Published online: 24 July 2020

(C) Springer Nature B.V. 2020

The end of World War II, whose 75th anniversary was to have been solemnly commemorated all across the world this year, was marked with an unprecedented attempt by the war's victors to definitively validate the elementary moral principles of warfare - hitherto only occasionally acknowledged in the peace settlements terminating previous military conflicts. The manifest objective of what would go down in history as the Nuremberg trials was accomplished only to a limited extent, both in terms of the scope of the events subject to criminal investigation, and the actual efficiency of the procedures employed in bringing to justice even the most notorious perpetrators of the war crimes of 1939-1945. Nonetheless, the vindication of the morality of war which the trials achieved has proved to be permanent. Providing, or at least tacitly assuming an ethically informed account of any of the armed conflicts that have broken out ever since has remained the basic condition for making a reasonable argument related to the given conflict. As any statement concerning the moral aspects of a military operation must necessarily entail a number of systematized normative beliefs about war as such, a general ethical theory of war (or a just war theory) has become an indispensable reference point in the public debates on the - unfortunately - everrecurring instances of armed hostilities.

Much of the current theorizing about the morality of war draws heavily on the seminal concepts and interpretations proposed centuries ago. Whether it is the requirements of just cause and right intention, the principle of double effect, or particular norms specifying the permissible conduct of warfare, almost all the basic components of theoretical models aimed at depicting a justified military action can be traced back to philosophical disputes waged by prominent medieval scholars (even if some of the modern construals of those concepts differ significantly from their original meaning). With such a long and rather convoluted history of philosophical speculation on the phenomenon of war - a significant part of it having been developed in direct response to actual military conflicts - it should come as no surprise that the present day discussions on the fundamentals of military ethics are still far from coming to an

Adam Cebula

a.cebula@uksw.edu.pl

1 Wydzial Filozofii Chrzescijanskiej, Uniwersytet Kardynala Stefana Wyszynskiego, Warsaw, Poland 
end. After all, considering the variety of argumentative strategies pursued by the participants in these debates - oftentimes based on mutually incompatible assumptions - one can hardly expect any conclusive outcomes of the debates to be achieved soon. At the same time, contemporary just war theorists are facing new challenges, ones resulting from the advancement of military technology, the development of new methods of warfare, as well as the emergence of novel forms of struggle for political power that involve the employment of military measures.

The following brief symposium on just war theory opens with a paper by Michael Walzer, who points out the legacy of the Nuremberg trials as a "world government" moment, one that made the moral dimension of war uniquely palpable. It also recapitulates the main principles of war ethics - laid out comprehensively in Walzer's famous book on just and unjust wars - as effectively substantiated (in the author's view) by the verdicts delivered during the trials. The other three papers examine various issues related to just war theory thus conceived: the first one analyzes the particular significance of Aquinas's principle of double effect for JWT-based reasoning about armed hostilities; the second challenges the validity of the principle of the moral equality of combatants when applied in the context of a total war; whereas the third attempts to outline a viable normative approach to counterinsurgency warfare. While dealing with essentially distinct aspects of military ethics, all three papers highlight the gravity of matters confronting today's just war theorists. They also testify to the immensity of the research area outlined in Walzer's Just and unjust wars (and now referenced in his Nuremberg article).

Strangely enough, several basic premises for theorizing on the moral aspects of war still remain insufficiently acknowledged by the general public. The absence of widespread popular commitment to what might seem to be intuitively obvious moral norms applicable to warfare was demonstrated in a recent empirical study conducted among Americans. ${ }^{1}$ On the other hand, just war theorists have to take account of the still unfinished debate over the tragic experiences of several generations of people directly or indirectly affected by the hecatomb of World War II. The recent discussions in Poland - Nazi Germany's first military target - on the methods of armed resistance to the installation of the communist regime in the country in the aftermath of the war exemplify but one of the possible challenges to contemporary speculation on the morally permissible resort to military measures. It will take some time before the enduring legacy of the Nuremberg trials becomes fully recognized and appreciated.

Publisher's Note Springer Nature remains neutral with regard to jurisdictional claims in published maps and institutional affiliations.

\footnotetext{
${ }^{1}$ S. D. Sagan and B. A. Valentino, Just War and Unjust Soldiers: American Public Opinion on the Moral Equality of Combatants, in: Ethics \& International Affairs, 33, no.4 (2019), 411-444.
} 